\title{
Spring water quality and human health: an assessment of natural springs of margalla hills Islamabad zone- III
}

\begin{abstract}
Water is the earth's most valuable compound that is fundamental for humans as well as all other living forms and seems to be inexhaustible. Unfortunately the outlook for the world's fresh water supply is not very hopeful. Moreover shortage of fresh water throughout the world can be directly attributed to human misuse in the form of pollution. Water is used for number of purposes like drinking, bathing and washing etc. so it must be free from toxic materials for healthy human and aquatic life. Among surface waters, springs' water is usually considered as safe for drinking. In the present study, springs' water of Margalla Hill Zone III Islamabad was assessed to clarify the concern about the quality and safety of this water used for drinking purposes in terms of physico-chemical (color, temperature, $\mathrm{pH}$, odor, turbidity, hardness, TDS, EC, alkalinity, $\mathrm{DO}, \mathrm{Cl}^{-}, \mathrm{NO}_{2}^{-}, \mathrm{NO}_{3}{ }^{2-}, \mathrm{SO}_{4}^{2-}$, heavy metals) and microbiological parameters (total Coliform, Pseudomonas aeruginosa, Enterococcus and Staphylococcus auerus). For this purpose, 15 water samples were collected from five different sites of Margalla Hills. Results showed that WHO drinking water standards were exceeded for EC, DO, cadmium, lead and microbiological parameters which may be detrimental for human health if water is consumed on daily basis. All other selected parameters did not exceed WHO drinking water standards and therefore, water from the sampling area does not pose any significant threat to consumer's health.
\end{abstract}

Keywords: drinking water, human health, coliforms, natural springs, margalla hills
Volume 2 Issue I - 2018

\author{
Aniqa Batool,' Nafeesa Samad,' Syeda \\ Sabahat Kazmi, ${ }^{2}$ Muhammad Asad Ghufran, ${ }^{3}$ \\ Saima Imad, ${ }^{2}$ Mateen Shafqat,' Tariq \\ Mahmood' \\ 'Department of Environmental Sciences, Pir Mehr Ali Shah-Arid \\ Agriculture University Rawalpindi, Pakistan \\ ${ }^{2}$ National Physical and Standardization Laboratories, Pakistan \\ ${ }^{3}$ Department of Environmental Sciences, International Islamic \\ University Islamabad, Pakistan
}

Correspondence: Aniqa Batool, Department of Environmental Sciences, Pir Mehr Ali Shah-Arid Agriculture University Rawalpindi, Pakistan, Email aniqabatool@uaar.edu.pk

Received: August II, 2017 | Published: February 02, 2018

\section{Introduction}

All life forms especially humans depend on their surrounding biophysical environment for their well-being and survival but due to overuse of these resources, environment has been degrading rapidly. Among these fundamental resources, water is one of the most important natural resource for humans, wildlife and the whole environment. Assessment of ambient water quality determines its use for humans and ecological purposes. ${ }^{1,2}$ Anthropogenic activities make the surface and ground water highly polluted ${ }^{3}$ owing to the fact that surface water is extensively being used in industrial activities, agriculture sector, domestic and municipal facilities. As clean water is highly demanded, it can be derived from various sources but unfortunately, surface waters most often have threat of begin polluted and their low quality status leads to public health issues. ${ }^{4}$ Water can be derived from many natural sources e.g. surface waters, streams, rivers, lakes and springs and it seems to be the best source for drinking and domestic water use for the population residing the surrounding area. Although, water is an essential component of life but it contains many undesirable substances in the polluted state which are highly dangerous to human health. ${ }^{5}$ Entering of these undesirable substances into food chain causes serious health hazards all over the world. Developing countries of Asia especially Pakistan, India, Bangladesh and other neighboring countries are facing serious health problems due to contaminated water. ${ }^{4,6}$ So there is a dire need of valuation of the drinking water in order to assess its safety for human consumption. As compared to developed countries, in developing countries i.e. Pakistan legislation for water resource management is weak and less work has been conducted on the issue of water contamination. ${ }^{7}$ Rules and regulations regarding water quality in Pakistan has been set by Pakistan Environmental Protection Agency (Pak-EPA), known as National Environmental Quality Standards (NEQS) which give the standards of water pollution. Through these standards, water quality is monitored at domestic and industrial level ${ }^{8}$ but still there is need of improvement in legislature structure regarding environmental quality standards with special concern of water in Pakistan. For better human health, it is extremely important to establish drinking water quality standards and criteria that are chemically balanced and medically safe. Water quality assessment is obtained chiefly by monitoring of physical, chemical and biological parameters. ${ }^{9}{ }^{90}$ Many natural springs originate from hilly areas of Murree and Margalla in Pakistan. Water of these springs make its route downward and is utilized by the local people as it passes from residential area. Keeping in view the use of these springs' water for daily consumption by the surrounding population, it is crucial to assess its quality. For this purpose, samples from different locations were collected for the assessment of specific parameters necessary for drinking water. Physicochemical parameters including color, temperature, $\mathrm{pH}$, odour, turbidity, hardness, total dissolve solids (TDS), electrical conductivity (EC), alkalinity, dissolved oxygen (DO), chlorides $\left(\mathrm{Cl}^{-}\right)$, nitrite $\left(\mathrm{NO}_{2}^{-}\right)$, nitrate $\left(\mathrm{NO}_{3}{ }^{2-}\right)$, sulphate $\left(\mathrm{SO}_{4}^{2-}\right)$ heavy metals and microbiological parameters including total Coliform, Pseudomonas aeruginosa, Enterococcus and Staphylococcus auerus were selected to assess the springs' water quality for drinking purposes. The main focus of the study was to:

i. Assess the water quality of Margalla Hills Zone III springs in terms of their physical, chemical and biological parameters.

ii. Make comparison of assessed parameters with WHO standards for portable water to predict its potential human health risks; and finally

iii. Make another comparison of selected springs of Margalla Hills Zone III with each other in order to identify the safe drinking water points. 


\section{Materials and methods}

\section{Sampling site}

The Margalla hills originating from the foothills of the Himalayas are a series of small elevation hills located at north of Islamabad, Pakistan. Margalla range covers an overall area of 12,605 hectares. The metropolitan twin cities of Pakistan, Islamabad and Rawalpindi are located near these hills, lie between longitudes $72^{\circ} 45^{\prime}$ and $73^{\circ} 30^{\prime}$ E. and latitudes $33^{\circ} 30^{\prime}$ and $33^{\circ} 50^{\prime} \mathrm{N}$. Rapid growth of both Islamabad and Rawalpindi to a combined population nearly 1.3 million has made ever-increasing demands on natural resources which ultimately has caused adverse effects on the environment. Many natural springs originate from Margalla hills. In their way downstream water of these springs serve the surrounding population for daily consumption. Capital development authority (CDA) channelizes water from these springs to the adjoining areas through head works at various points. Mostly spring's water is used by the population of Ramli, Saidpur village, Dispensory area, Lower and Upper Shahdar (Figure 1).

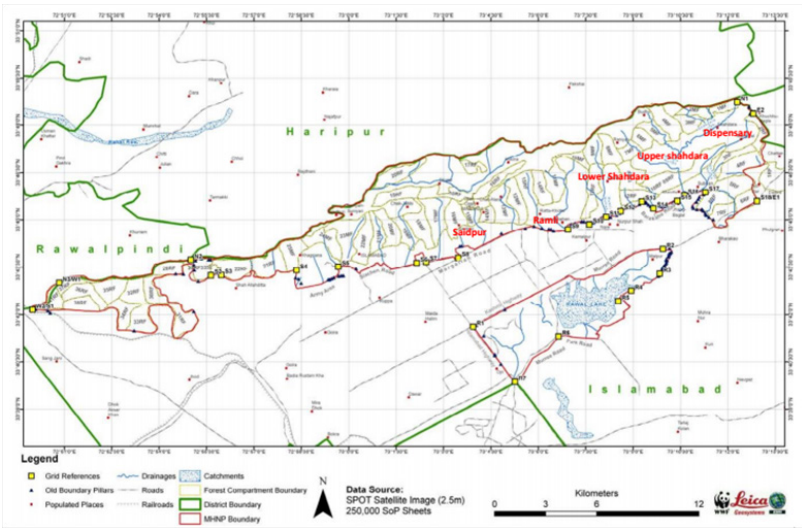

Figure I Map showing sampling sites in Magralla Hill Zone III, Islamabad.

\section{Sampling}

Total 15 samples were collected from 5 springs coming towards Islamabad. Most common sites were chosen from springs with high use for drinking purposes by the local population. These include Ramli, Dispensory area, Saidpur village, Lower and Upper Shahdara. Sampling and preservation of all samples were performed following the Standards Methods for Examination of Water and Wastewater. ${ }^{11}$

\section{Microbiological analysis}

Total Coliform, Pseudomonas aeruginosa, Enterococcus and Staphylococcus aeurius were determined by multiple tube technique, following $\mathrm{FAO}^{12}$ method and Standard method for water and wastewater. $^{11}$

\section{Physicochemical analysis}

$\mathrm{pH}$, Temperature, Conductivity and Dissolved Oxygen were determined on the sampling site by their respective potable apparatus. Alkalinity, Total Hardness and Chlorides were determined by titration method. Sodium and potassium were assessed using flame photometer. Analyses of metals ( $\mathrm{Zn}, \mathrm{Mn}, \mathrm{Cr}, \mathrm{Cd}, \mathrm{Pb}$ ) were performed by atomic absorption spectrophotometer. Nitrite, Nitrate and Sulphates were determined by using UV Spectrophotometer. All methods were according to Standard Method of Water and Wastewater. ${ }^{11}$

\section{Statistical analysis}

Descriptive statistics was used to calculate mean and Standard deviation of variables. One way analysis of variance (ANOVA) was used to test the overall difference between the means of variables in samples collected from different sampling sites. Ethical approval: This article does not contain any studies with human participants or animals performed by any of the authors.

\section{Results}

\section{Microbiological parameters}

At all selected points of springs on Margalla hill Zone III, from Ramli to Saidpur non-significant readings were observed for total Coliform. Highest mean value ( $>2400$ MPN index per $100 \mathrm{ml})$ was found in the samples of lower Shahdara and Dispensary. There was no significant difference in the count of Staphylococcus at the selected areas. Most probable number of Staphylococcus in water samples of different sites ranged from 4 to $>2400$ in $100 \mathrm{ml}$ of sample. There was no significant difference in springs' water with respect to presence of Enterococcus bacteria. It ranged between less than 2 to 540 MPN per $100 \mathrm{ml}$ (Table 1). Pseudomonas aeruginosa was present in all the water samples of springs of Magalla Hill Zone III. No significant difference was found in springs regarding to the number of Pseudomonas aeruginosa. Hundred milli liters of samples showed maximum amount of Pseudomonas aeruginosa in the waters of all selected areas.

Table I Descriptive statistics of microbiological parameters in springs' water samples

\begin{tabular}{|c|c|c|c|c|c|c|}
\hline Parameter & & & Total coliform & Staphylococcus & Enterococcus & Pseudomonas \\
\hline \multicolumn{7}{|c|}{ MPN index $/ 100 \mathrm{ml}$} \\
\hline \multicolumn{2}{|l|}{ WHO Standard } & \multicolumn{5}{|c|}{ Must not be Detectable in any $100 \mathrm{ml}$ of Sample } \\
\hline \multirow[t]{8}{*}{ Sampling Sites } & Ramli & Min & 540 & 240 & $<2$ & $>2400$ \\
\hline & & $\operatorname{Max}$ & $>2400$ & 1600 & 49 & $>2400$ \\
\hline & & Mean & $1780 \pm 1073.9$ & $693.3 \pm 785.2$ & $31 \pm 25.6$ & $2400 \pm 0.0$ \\
\hline & Lower Shahdara & Min & $>2400$ & 540 & $<2$ & $>2400$ \\
\hline & & $\operatorname{Max}$ & $>2400$ & $>2400$ & 130 & $>2400$ \\
\hline & & Mean & $2400 \pm 0.0$ & $1513.3 \pm 933.02$ & $64 \pm 64.1$ & $2400 \pm 0.0$ \\
\hline & Upper Shahdara & Min & 540 & 240 & 23 & $>2400$ \\
\hline & & $\operatorname{Max}$ & $>2400$ & 540 & 130 & $>2400$ \\
\hline
\end{tabular}


Table Continued....

\begin{tabular}{|c|c|c|c|c|c|c|}
\hline Parameter & & & Total coliform & Staphylococcus & Enterococcus & Pseudomonas \\
\hline \multicolumn{7}{|c|}{ MPN index $/ 100 \mathrm{ml}$} \\
\hline \multirow[t]{6}{*}{ WHO Standard } & & \multicolumn{5}{|c|}{ Must not be Detectable in any $100 \mathrm{ml}$ of Sample } \\
\hline & & Max & $>2400$ & 1600 & 240 & $>2400$ \\
\hline & & Mean & $2400 \pm 0.0$ & I | $46.6 \pm 785.2$ & $81.3 \pm 137.4$ & $2400 \pm 0.0$ \\
\hline & & Max & $>2400$ & 240 & 540 & $>2400$ \\
\hline & & Mean & $2133.3 \pm 461.9$ & $89 \pm|3| . \mid$ & $280 \pm 242.5$ & $2400 \pm 0.0$ \\
\hline & & P-value & 0.69 & 0.124 & 0.23 & \\
\hline
\end{tabular}

\section{Physical parameters}

There was no detectable smell in springs' water samples. $\mathrm{P}<0.05$ indicates significant difference in the temperature of these springs' waters. Minimum temperature was recorded in the samples taken from Saidpur village and maximum was in the water samples of Upper Shahdara and Dispensary. The mean values of $\mathrm{pH}, \mathrm{EC}$, alkalinity and DO in samples of Margalla Hills were significant different from each other. Values of these parameters ranged between 6.97-7.65, $0.51-0.65 \mathrm{mS} / \mathrm{cm}, 379.3-660.7 \mathrm{mg} / \mathrm{L}$ and $9.2-18.6 \mathrm{mg} / \mathrm{L}$ for $\mathrm{pH}, \mathrm{EC}$, alkalinity and DO respectively (Figure 2). Where-as non-significant difference was observed for turbidity, hardness and TDS and their values vary from 0.257 to $0.4 \mathrm{NTU}, 35.36-42.7 \mathrm{mg} / \mathrm{L}$ and $257.6-$ $370.33 \mathrm{mg} / \mathrm{L}$ respectively (Figure 2 ).
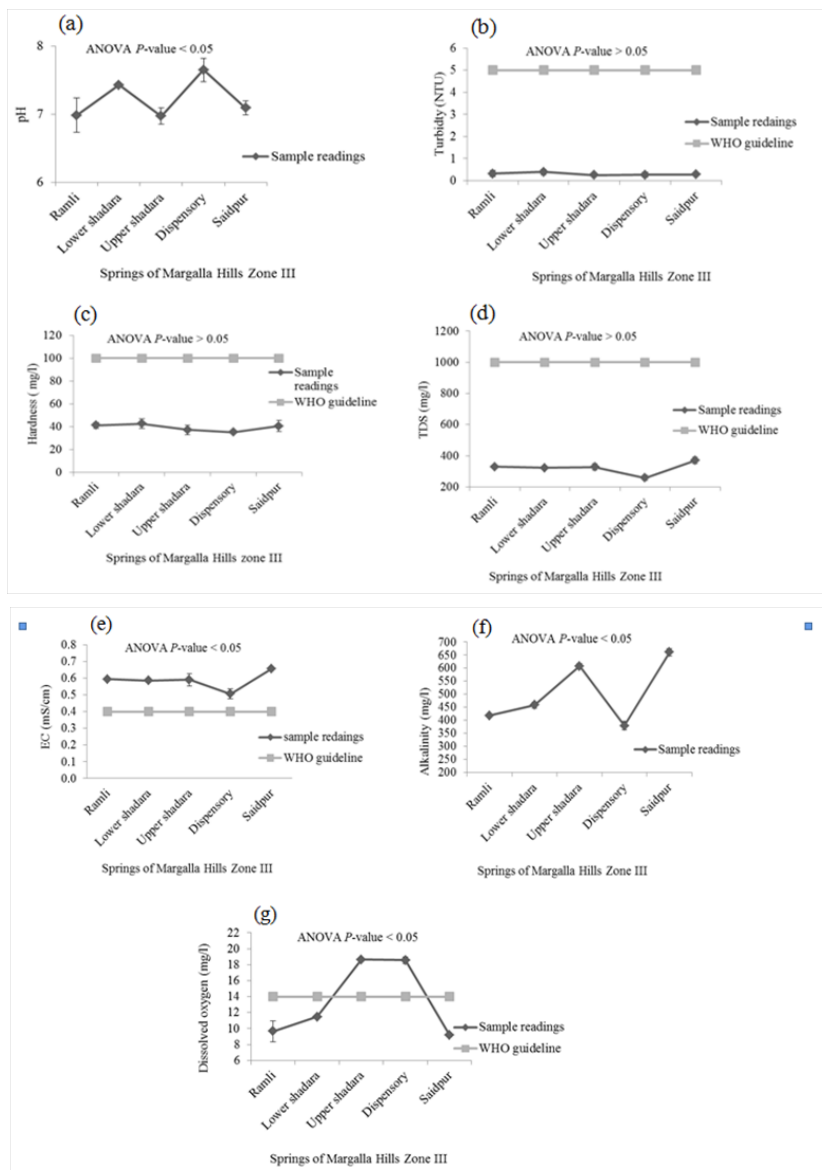

Figure 2 Comparisons of physical parameters [a, $\mathrm{pH} ; \mathrm{b}$, Turbidity; $\mathrm{c}$, Hardness: d, TDS; e, EC; f, Alkalinity; g, Dissolved Oxygen] of springs' water with WHO standard. Values presented are mean \pm SE $(n=3)$.

\section{Chemical parameters}

Data analysis of nitrate, sulphate, sodium, potassium, zinc, copper, manganese and lead showed no significant difference in the mean values for springs' water samples taken from five different sites of Margalla hills. Nitrate was present in the source samples with a range of 5.6 to $9.8 \mathrm{mg} / \mathrm{L}$, sulphate with 172.16 to $184.3 \mathrm{mg} / \mathrm{L}$, sodium with 8 to $12.8 \mathrm{mg} / \mathrm{L}$, potassium with 1.467 to $3.66 \mathrm{mg} / \mathrm{L}$, zinc with 0.001 to $0.013 \mathrm{mg} / \mathrm{L}$, copper with 0.001 to $0.012 \mathrm{mg} / \mathrm{L}$, manganese with 0.021 to $0.1 \mathrm{mg} / \mathrm{L}$ and lead with 0.00 to $0.144 \mathrm{mg} / \mathrm{L}$ and non-significant difference was found in case of chloride, ranging between 16.3 to $23.3 \mathrm{mg} / \mathrm{L}$ and cadmium varied from 0.00 to $0.014 \mathrm{mg} / \mathrm{L}$ (Figure 3 ).

\section{Discussion}

High value of MPN index for total coliform showed alarming results at all selected sites on Margalla Hill, as according to WHO guideline for portable water, total Coliform must not be detectable in $100 \mathrm{ml}$ of sample (Table 1). Khan et al. ${ }^{7}$ also observed high fecal contamination in ground and surface drinking water along River Swat in Swat district, Pakistan, which indicates the contamination of water with human or animal fecal waste and other bacteria from the soil. Maximum numbers of Staphylococcus type of bacteria were present in the spring of Lower Shahdara and minimum numbers of bacteria were found in the spring of saidpur village (Table 1), while it was recommended that there should not be any pathogenic Staphylococcus spp. in $100 \mathrm{ml}$ of drinking water ${ }^{13}$ which make it unsuitable for drinking because all over the world nosocomial and community-acquired infections, skin infections and other lethal diseases like meningitis, osteomyelitis, endocarditis, toxic shock syndrome (TSS), pneumonia, chest pain and bacteremia are mostly caused by Staphylococcus aureus. ${ }^{14,15}$ Enterococcus spp. are hygiene indicator bacteria all over the world. Although at all sampling sites low Enterococcus count was observed as compared to other microbiological parameters but their presence indicates the unhygienic condition of springs' water. Pseudomonas spp. are very common in water systems due to their ease of colonization and they form thick biofilms which consequently have an effect on turbidity, taste and odor of drinking water. ${ }^{13}$ Springs' water samples collected from all the five different sites of Margalla hill showed maximum count of Pseudomonas per $100 \mathrm{ml}$. Pseudomonas in drinking water can cause serious health hazard in an immune-compromised population and usually infect the urinary tract, pulmonary tract, wounds and burns. ${ }^{16} \mathrm{pH}$ and turbidity are the most important parameters for testing of water quality and it is a useful tool of interpretation of water chemistry. ${ }^{6,7}$ In this study, mean values of $\mathrm{pH}$ of all points followed the WHO recommended limits except water samples of Dispensary area, where the mean value of $\mathrm{pH}$ (7.65) was slightly above the WHO recommended limit (Figure 2A). Same range (6.9 to 9.2) of $\mathrm{pH}$ was observed by Virkutyte \& Sillanpaa ${ }^{17}$ in 
portable water of Eastern Qinghai province, China. While turbidity level was found below WHO recommended limit ( 5 NTU) in all water samples of springs (Figure $2 \mathrm{~B}$ ). It was suggested by $\mathrm{WHO}^{13}$ that turbidity less than $5 \mathrm{NTU}$ is acceptable for daily consumption and for health purpose it should be less than 1 NTU. High turbidity in water hinders the disinfection of pathogenic microorganisms, thus it can cause health risk. ${ }^{18}$ Passage of water through mineral rocks naturally adds $\mathrm{Ca}$ and $\mathrm{Mg}$ in the water which in turn increase water hardness. ${ }^{19}$ Margalla hills are mainly comprised of mineral rocks i.e. limestone, sandstone and shale, therefore, increasing trend in hardness was observed as the water moves down the hill (Figure 2C). At all selected points, values of hardness ranged within the permissible limit $(100 \mathrm{mg} / \mathrm{L})$. It was reported that there exists an inverse relationship between water hardness and cardiovascular diseases. ${ }^{20}$ It may also affect the taste of water due to increase in TDS. ${ }^{19}$ Conductivity measures the ability of water to conduct in electrical current, and is directly related to the TDS. ${ }^{19}$ This direct relationship can also be observed in present study which showed that with increase in EC as water moves down the hill, level of TDS also increased (Figure 2E \& Figure2D). EC ranged from $0.51 \mathrm{mS} / \mathrm{cm}$ to $0.65 \mathrm{mS} / \mathrm{cm}$ which is more than permissible limit of WHO $(0.4 \mathrm{mS} / \mathrm{cm})$ (Figure 2E). The high level of EC can be due to significant amount of dissolved salts, high salinity and mineral contents. ${ }^{21-23}$ Alkalinity of water is not regarded as a pollutant so no limit is recommended by WHO for safe drinking water. High alkalinity values reflect high carbonate and bicarbonate ions and direct association between $\mathrm{EC}$ and alkalinity was reported by Thomaz et al. ${ }^{24}$ Alkalinity of surface water is related to the geology of the area. As magalla hills comprised of limestone so alkalinity of springs' water samples ranged between $379.3 \mathrm{mg} / \mathrm{L}$ and $660.7 \mathrm{mg} / \mathrm{L}$ (Figure 2F). Biological, chemical and physical processes may be affected by increase or decrease in dissolved oxygen. ${ }^{22}$ Water samples taken from Upper Shahdara and Dispensary, level of DO was found $18.6 \mathrm{mg} / \mathrm{L}$ (Figure 2G). Dissolved oxygen in water samples taken from Ramli, Lower Shahdara and Saidpur were below the recommended limit of WHO $(14 \mathrm{mg} / \mathrm{L})$ which doesn't make it feasible for drinking. High concentration of chloride is a risk for human health and it also causes bad taste of water. ${ }^{25}$ Drinking water containing nitrate, is a sign of organic pollution which can be added to water through agriculture, industrial effluents and domestic waste. The study of Entry \& Farmer ${ }^{26}$ revealed that elevated amount of nitrate from safe limits can cause "blue baby" syndrome and it is also linked with stomach cancer, birth defects, miscarriage, leukemia, non Hodgkin s' lymphoma, reduced body growth, slow reflex and increased thyroid size. Saleh et al. ${ }^{27}$ mentioned that intake of high concentration of sulphate can cause dehydration, catharsis and gastrointestinal irritation. In present study, the concentration of chloride, nitrate and sulphate in springs' water were below the permissible limit which refers it safe for human consumption (Figure 3A-3C). Sodium is very essential for nerve and muscles functioning, on the other hand high concentration of sodium may cause kidney damage and also increase the chances of high blood pressure. Adverse health effects due to potassium intake through drinking water are unlikely to occur in healthy individuals. Karavoltsos et al. ${ }^{5}$ mentioned in his study that potassium did not impose any health effects but it can cause unpleasant taste and corrosion of pipes. In this study, concentration of sodium and potassium in water samples of springs was below the WHO recommended limit so it can be used for drinking, based on sodium and potassium concentration (Figure $3 \mathrm{~d} \& 3 \mathrm{e})$. Drinking water is a well-recognized pathway of exposure to heavy metals. ${ }^{28,29}$ Zinc concentration was almost negligible at all selected location. Photo toxicity in plants and relatively low toxicity in animals and humans was mainly due to zinc. ${ }^{30}$ Cadmium was present in all source samples except Upper Shahdara where the amount of cadmium was not detectable and mean value $(0.001 \mathrm{mg} / \mathrm{L})$ of cadmium at Dispensary was found to be very negligible. Cadmium concentrations showed alarming results in water samples taken from Ramli and Lower Shahdara by exceeding the permissible limits of WHO standards (Figure $3 \mathrm{~g}$ ) which made it unsafe for drinking. WHO limit for cadmium is $0.003 \mathrm{mg} / \mathrm{L}$ in safe drinking water. Concentration of copper and manganese at all points varies below WHO permissible limits (Figure 3H) (Figure 3I). Variation in copper concentrations may be due to its dependence on the properties of hardness, $\mathrm{pH}$, anion concentration, oxygen concentration and temperature. ${ }^{31}$ Health effects related with high concentration of copper are liver and kidney damage, gastrointestinal distress while at low concentration it may cause vomiting and nausea. ${ }^{32} \mathrm{Health}$ effects in case of elevated amount of $\mathrm{Mn}$ are apathy, irritability, headache, insomnia, gastrointestinal irritation and respiratory diseases. ${ }^{33}$ Carcinogenicity caused by lead in humans is one of the concerning factor to define its safe limits in drinking water. ${ }^{13}$ In present study, lead conc. showed alarming result for water samples of Ramli, Lower shahdara and Saidpur by exceeding the WHO recommended limits (Figure 3J). ${ }^{34-39}$
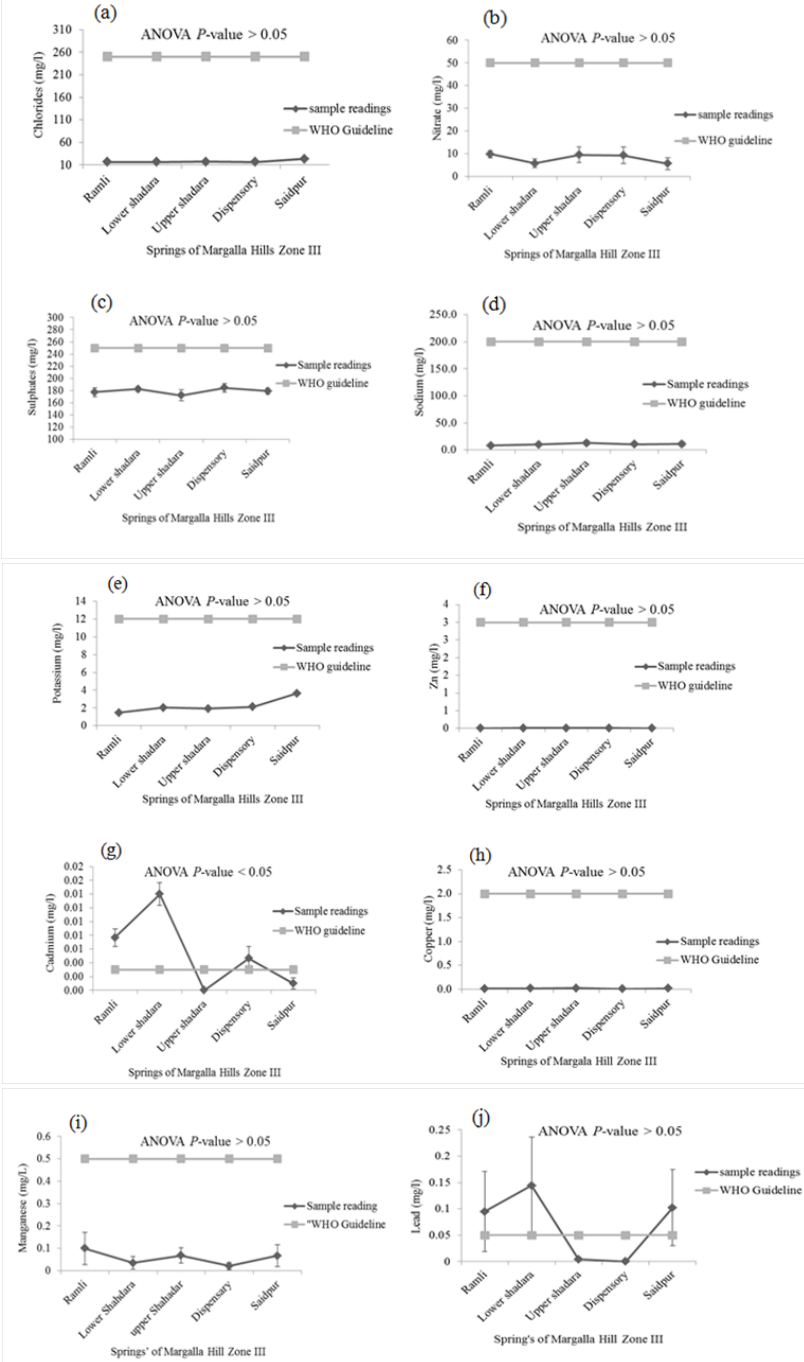

Figure 3 Comparisons of chemical parameters [a, Chlorides; b, Nitrate; c, Sulphates; d, Sodium; e, Potassium; f, Zn; g, Calcium; h, Copper; I, Manganese; j, Lead] of springs' water with WHO standards. Values presented are mean \pm SE $(n=3)$. 


\section{Conclusion}

It can be concluded from the analyses that the quality of water of springs has declined on the basis of all microbiological parameters and some physico-chemical parameters i.e. EC, DO, cadmium and lead. Mostly, physico-chemical parameters were found below the WHO recommended limit.

\section{Recommendations}

Following are some main ideas of serious concern:

a. People should be trained to use boiling or filtration techniques to remove microbiological contamination before consuming springs' water for drinking.

b. Authorities should start public awareness programs so that people adopt appropriate measures to protect one of the most valuable fresh water resource.

c. Springs' water should be channelized to the surrounding areas through pipes to avoid their contamination by anthropogenic activities.

d. Government should install treatment plants to make springs' water free from physico-chemical and microbiological contaminations.

\section{Acknowledgements}

We are thankful to National Physical and Standardization Laboratories (NPSL) Islamabad for practical support and assistance in field sampling and analytical work.

\section{Conflict of interest}

Authors declare there is no conflict of interest in publishing the article.

\section{References}

1. Gunnarsdottir MJ, Gardarsson SM, St. Jonsson G, et al. Chemical quality and regulatory compliance of drinking water in Iceland. Int J Hyg Environ Health. 2016;219(8):724-733.

2. Chang H. Spatial analysis of water quality trends in the Han River basin, South Korea. J Water Res. 2008;42(13):3285-3304.

3. Su J, Ji D, Lin M, et al. Developing surface water quality standards in China. Resour Conserv Recycl 2017;117 (Pt B):294-303.

4. Yan W, Li J, Bai X. Comprehensive assessment and visualized monitoring of urban drinking water quality. Chemometr Intell Lab Syst. 2016;155(15):26-35.

5. Karavoltsos S, Sakellari A, Mihopoulos N, et al. Evaluation of the quality of drinking water in regions of Greece. Desalination. 2008;224(1-3):317-329.

6. Baig JA, Kazi TG, Arain MB, et al. Evaluation of arsenic and other physico-chemical parameter of surface and ground water of Jamshoro, Pakistan. J Hazardous Materials. 2009;166(2-3):662-669.

7. Khan K, Lu Y, Saeed MA, et al. Prevalent fecal contamination in drinking water resources and potential health risks in Swat, Pakistan. $J$ Environ Sci. 2017.

8. Azizullah A, Peter R, Donat PH. Ecotoxicological Evaluation of Wastewater Samples from Gadoon Amazai Industrial Estate (GAIE), Swabi, Pakistan. International Journal of Environmental Sciences. 2011;1(5):966-983.

9. Loukas A. Surface water quality and quality assessment in Pinios River, Thessaly, Greece. J Desalination. 2010;250(1):266-273.
10. Bouyacioglu $\mathrm{H}$. Surface water quality assessment using factor analysis. $J$ Water SA. 2006; 3:389-393.

11. APHA. Standard Methods for the Examination of Water and Wastewater 21st edn. American public Health Association, USA; 2005.

12. FAO. Manual of Food Quality Control: 4. Microbialanalysis. Food and Agriculture Organization of the United Nations. USA; 1992. p. 1-344.

13. WHO. Guidelines for Drinking Water Quality. 4th edn, World Health Organization, USA; 2011. p. 1-564.

14. Jarraud S, Mougel C, Thioulouse J, et al. Relationships between Staphylococcus aureus genetic background, virulence factors, agr groups (alleles), and human disease. Infect Immun. 2002;70(2):631-641.

15. Yassin AN, Marjolein FQ, Vanden, et al. Nasal carriage of multiresistant Staphylococcus aureus among health care workers and pediatric patients in hospitals in Mogadishu, Somalia. Int J Infect Dis. 1997;1(4):186-191.

16. Mena KD, Gerba CP. Risk Assessment of Pseudomonas aeruginosa in Water. Rev environ contam toxicol. 2009;201:71-115.

17. Virkutyte J, Sillanpaa M. Chemical evaluation of potable water in Eastern Qinghai Province China: Human health aspects. Env Int. 2016;32(1):80-86

18. Zvikomborero H. An assessment of the water quality of drinking water in rural districts in Zimbabwe. The case of Gokwe South, Nkayi, Lupane, and Mwenezi districts. Phy Chem Earth. 2005;30(11-16):859-866.

19. Rossiter HMA, Owusu PA, Awuah E, et al. Chemical drinking water quality in Ghana: Water costs and scope for advanced treatment. Sci Total Environ. 2010;408(11):2378-2386.

20. Yang CY, Cheng MF, Tsai SS, et al. Calcium, magnesium and nitrate in drinking water and gastric cancer mortality. Japenese $J$ Cancer Res. 1998;89(2):124-130.

21. Arain MB, Kazi TG, Jamali MK, et al. Total dissolved and bioavailable elements in water and sediment samples and their accumulation in Oreochromis mossambicus of polluted Mancher Lake. Chemosphere. 2009;70(10):1845-1856.

22. Kazi TG, Arain MB, Jamali MK, et al. Assessment of water quality of polluted lake using multivariate statistical techniques: A case study. $J$ Ecotoxicol Environ Safety. 2009;72(2):301-309.

23. Zacheus OM, Martikainen PJ. Physicochemical quality of drinking and hot waters in Finnish buildings originated from groundwater or surface water plants. Sci Total Environ. 1997;204(1):1-10.

24. Thomaz SM, Lansac TFA, Roberto MC, et al. Seasonal variation of some limnological factors of lagoa do Guarana, a Varzea lake of the high Rio Parana, State of Mato Grosso do Sul, Brazil. Revue d'Hydrobiolgie Tropicale. 1992;25:269-276.

25. Versari A, Parpinello GP, Galassi S. Chemometric survey of Italian bottled mineral waters by means of their labeled physico-chemical and chemical composition. J Food Compos Anal. 2002;15(3):251-264.

26. Entry JA, Farmer N. Ground water quality: movement of coliform bacteria and nutrients in groundwater flowing through basalt and sand aquifers. J Environ Qual. 2001;30(5):1533-1539.

27. Saleh MA, Ewane E, Jones J, et al. Chemical evaluation of commercial bottled drinking water. J Food Compos Anal. 2001;14(2):127-152.

28. Chowdhury S, Mazumder MAJ, Al Attas O, et al. Heavy metals in drinking water: Occurrences, implications, and future needs in developing countries. Sci Total Environ. 2016;569-570:476-488.

29. Ryan PB, Huet N, Madntosh DL. Longitudinal investigation of arsenic, cadmium and lead in drinking water. Env Health Perspective. 2000;108(8):731-735.

30. Allowary BJ, Aures PC. Chemical principles of environmental pollution. Lackie Academic \& Professional. UK; 1994. p. 1-291. 
31. Boulay N, Edwards M. Role of temperature, chlorine and organic matter in copper corrosion by-product release in soft water. Water Res. 2001;35(3):683-690.

32. Pyatt FB, Pyatt AJ, Walker C, et al. The heavy metal content of skeleton from an ancient metalliferous polluted area in Southern Jordan with particular reference to bioaccumulation and human health. Ecotoxicol Environ Safety. 2005;60(3):295-300.

33. Apostoli P, Lucchini R, Alessio L. Are current biomarkers suitable for the assessment of manganese exposure in individual workers?. Am J Ind Med. 2000;37(3):283-390.

34. Beamonte E, Bermuder JD, Casino A, et al. A statistical study of quality of surface water intended for human consumption near Valencia (Spain). J Environ Manag. 2007;83(3):307-314.

35. Jarraud S, Mougel C, Thioulouse J, et al. Relationships between Staphylococcus aureus genetic background, virulence factors, agr groups (alleles), and human disease. Infect Immun. 2002;70(2):631-641.
36. Kunte DP, Yeole TY, Chiplonkar SA, et al. Inactivation of Salmonella typhi by high levels of volatile fatty acids during anaerobic digestion. $J$ Appl Microbiol. 1998;84(1):138-142.

37. Olaoye OA, Onilude AA. Assessment of microbiological quality of sachet-packaged drinking water in Western Nigeria and its public health significance. Public Health. 2009;123(11):729-734.

38. Santos A, Alonso E, Callejon M, et al. Heavy metal content and speciation in groundwater of the Guadiamar river basin. Chemosphere. 2002;48(3):279-285.

39. Friberg L, Nordberg GR, Bouk BB. Handbook on the Toxicology of Metals. Elsevier press, USA; 1986. 